Institute of $\mathbf{F}_{\text {ood and }} \mathbf{A}$ gricultural $\mathbf{S}_{\text {ciences }}$

\title{
Irrigation Scheduling As a Means of Applying the Right Water Amount and Monitoring Soil Moisture for Vegetable Crops Grown in Florida in the BMP Era ${ }^{1}$
}

\section{Eric Simonne and George Hochmuth ${ }^{2}$}

This publication is one of a series entitled Fertilizer and Irrigation Management in the BMP Era. This series is divided into nine principles described in the Introduction Chapter (HOS-897). This

publication is part of Principle 5, "Irrigation Amount Must Reflect Crop Water Use ... No More, No Less." BMP implementation requires a global approach to production management. However, for presentation purposes, each aspect of vegetable production is described in a separate publication.

Irrigation scheduling is used to determine when to irrigate a crop and how much water to apply. Although average rainfall in Florida is approximately 50 inches per year, rainfall distribution is often non-uniform, and comes during seasons when crops might not be grown. In addition, Florida's sandy soils have low water holding capacity and seldom can store more than one day's worth of crop water use.

Random irrigation (not knowing when or how much to apply) and the feel-and-see method (applying a pre-determined amount of water when the soil feels dry or when the crop begins to wilt) are likely to result in reduced yield because of crop water stress and/or nutrient leaching. Proper irrigation management for vegetables grown in Florida requires the determination of a target irrigation amount and an accurate measurement of soil moisture status.

\section{Working Definition}

Irrigation scheduling is planning how much water to apply and when to apply with the highest possible efficiency.

\section{Irrigation Management - Estimating ET - Things to Do}

- Always manage irrigation and fertilization together. Remain knowledgeable on irrigation issues; avoid the guessing. Poor irrigation management negates the potential benefits of a well-designed fertilization program.

- Irrigation amount (target volume) should aim at replacing daily crop evapotranspiration (ETc). ETc may be determined from actual reference evapotranspiration (ETo), historical ETo, class A pan evaporation, or empirical values when no other estimates are available. For information, consult IFAS Bulletin AE260 "Principles and

1. This document is HS909, one of a series of the Horticultural Sciences Department, Florida Cooperative Extension Service, Institute of Food and Agricultural Sciences, University of Florida. Publication date: January 2003. Please visit the EDIS Web site at http://edis.ifas.ufl.edu.

2. Eric Simonne, assistant professor, George Hochmuth, center director, NFREC-Quincy, Horticultural Sciences Department, Cooperative Extension Service, Institute of Food and Agricultural Sciences, University of Florida, Gainesville, 32611. 
Practices of Irrigation Management for

Vegetables", http://edis.ifas.ufl.edu/CV107.

- ETc should also account for the efficiency of the irrigation system.

- The amount of water applied in one irrigation event should not exceed the soil water holding capacity of the wetted area. When irrigation amounts larger than the water holding capacity of the wetted area are needed, then irrigation should be applied in two or three events (split applications).

- The irrigation system should be well maintained, and operated at the highest irrigation efficiency and uniformity possible.

- Water meters should be used to measure how much water is actually applied to the irrigated area. Water meters pay for themselves as they result in water and energy savings.

- Keep daily records of irrigation amounts applied and total rainfall received.

\section{Minimizing Water Losses - Things to do}

- Minimize conveyance (transport from water source to the field) losses by checking and repairing leaks regularly.

- Minimize application losses due to evaporation and wind drift by irrigating early in the morning.

- When irrigation events have been missed due to mechanical failures, do not try to catch up by applying a large irrigation amount. Instead, gradually restore soil moisture and monitor soil water tension (SWT).

- Use pipes instead of open ditches for conveyance of water in a sub-surface system.

\section{Irrigation Management: Soil-moisture Monitoring - Things To Do}

- Monitor soil moisture together with a target irrigation volume.
- Measure with tensiometers or other tested devices.

- Maintain SWT within the recommended range for the crop. For vegetable crops, this range is 8 $\mathrm{cb}$ (field capacity) to $15 \mathrm{cb}$.

- Allow SWT to fluctuate within the recommended range: if SWT remains near or at field capacity, over-irrigation and nutrient leaching may occur.

- Use tensiometers in pairs: one shallow, and one deep. For shallow-rooted vegetables, place one sensor at the 6-in depth, and the other at the 12-in depth.

- Ensure that the soil moisture measuring devices are correctly installed and maintained.

- Soil moisture may also be monitored with time domain reflectometry (TDR) or electrical conductivity (EC) probes, but recommendations may not be available by IFAS at this time.

- Keep daily records of SWT.

- Use correct water-release curves when measuring volumetric water content to determine the corresponding SWT.

\section{Things to Avoid: Potential Pitfalls}

- Avoid irrigations that fully replenish soil moisture when chances of rain are high. Instead, practice deficit irrigation.

- Do not use wide beds with plastic mulch when irrigation is provided overhead (linear moves, pivots, solid sets, traveling guns) as the mulch shields the root zone, thereby reducing irrigation efficiency.

- Do not alter existing irrigation systems without consulting an engineer first.

\section{Operation and Maintenance}

- Irrigation systems should be checked periodically for water application uniformity. 
- Application uniformities of $90 \%$ or better should be targeted for systems using fertigation.

\section{Other Considerations}

- Monitor well water quality regularly.

- Irrigation efficiency should be increased when designing or upgrading irrigation systems.

- Sub-surface and drip irrigation help reduce foliar disease incidence compared to overhead sprinkler systems since they do not wet foliage.

- Soil water holding capacity may be increased by increasing organic matter content by applying an organic amendment or planting a cover crop.

- Soil water tension is not a linear function of soil moisture.

\section{Additional Readings}

Fertilizer Application and Management for Micro (drip)-irrigated Vegetables in Florida, Circ. 1181, Fla. Coop. Ext. Ser., IFAS, Univ. of Fla. http://edis.ifas.ufl.edu/FR031

Principles and Practices of Irrigation Management for Vegetables, AE260, Fla. Coop. Ext. Ser., IFAS, Univ. of Fla. http://edis.ifas.ufl.edu/CV107

Basic Irrigation Scheduling in Florida, Bull. 249, Fla. Coop. Ext. Ser., IFAS, Univ. of Fla. http://edis.ifas.ufl.edu/AE111

Irrigation Scheduling with Evaporation Pans, Bull. 254, Fla. Coop. Ext. Ser., IFAS, Univ. of Fla. http://edis.ifas.ufl.edu/AE118

Efficiencies of Florida Agricultural Irrigation Systems, Bull. 247, Fla. Coop. Ext. Ser., IFAS, Univ. of Fla. http://edis.ifas.ufl.edu/AE110

Field Evaluation of Microirrigation Water Application Uniformity, Bull. 265, Fla. Coop. Ext. Ser., IFAS, Univ. of Fla. http://edis.ifas.ufl.edu/AE094
Tensiometers for Soil Moisture Measurement and Irrigation Scheduling, Circ. 487, Fla. Coop. Ext. Ser., IFAS, Univ. of Fla. http://edis.ifas.ufl.edu/AE146

Tensiometer Service, Testing and Calibration, Bull. 319, Fla. Coop. Ext. Ser., IFAS, Univ. of Fla. http://edis.ifas.ufl.edu/AE086 